Article

\title{
Fabrication and Characterization of Activated Carbon Fibers from Oil Palm Trunk
}

\author{
Jian Lin *, Rattana Choowang and Guangjie Zhao \\ Beijing Key Laboratory of Wood Science and Engineering, Beijing Forestry University, Beijing 100083, China; \\ rchoowang@sohu.com (R.C.); zhaows@bjfu.edu.cn (G.Z.) \\ * Correspondence: linjian0702@bjfu.edu.cn; Tel.: +86-10-6233-6907
}

Received: 5 November 2020; Accepted: 21 November 2020; Published: 24 November 2020

\begin{abstract}
To develop more valuable application, oil palm trunk was successfully converted into activated carbon fibers (ACFs). An effective process of chemical treatment with dilute sulfuric acid was conducted to improve the thermal stability of primary fibers for further heating treatment. Carbon dioxide $\left(\mathrm{CO}_{2}\right)$ was used as activator to produce much porous structure with various pore diameter. The specific surface area $\left(\mathrm{S}_{\mathrm{BET}}\right)$ and total pore volume $\left(\mathrm{V}_{\text {total }}\right)$ of resultant $\mathrm{ACFs}$ showed increasing trend as rise of activation temperature and time. The ACFs obtained under the temperature of $900{ }^{\circ} \mathrm{C}$ and time of 90 min exhibited highest $S_{\text {BET }}$ and $V_{\text {total }}$, which were more than $1800 \mathrm{~m}^{2} / \mathrm{g}$ and $0.7 \mathrm{~mL} / \mathrm{g}$, respectively. Meanwhile, more graphic carbon on the surface of ACFs were destroyed with prolonging activation time, resulting in the oxygen-containing functional groups formed during activation process with $\mathrm{CO}_{2}$. Due to the abundant pores and surface functional groups, the ACFs exhibited excellent adsorption capacity of chromium and would be an alternative material for industrial adsorption utilization.
\end{abstract}

Keywords: oil palm trunk; activated carbon fibers; porous structure; chromium removal

\section{Introduction}

As one of the most significant members in carbon family, activated carbon fibers (ACFs) are fibrous carbonaceous material and generally prepared from carbon fiber or precursor fibers by activation with some oxidized gas or chemical reagent at high temperature. During activation, large amounts of well-defined porous structures were formed through reaction between activator and fibers, leading to excellent adsorption properties and various applications, such as separation, electronic materials, purification, storage of natural gas and catalysts [1]. In general, ACFs were commercially manufactured by the procedures of spinning, thermostabilization, carbonization and activation from pitch, viscose rayon phenolic resin and polyacrylonitrile [2-5]. However, such raw materials for ACFs preparation are environment-unfriendly and limited resources. Thus, more and more research forced on the biomass resources as raw materials for fabricating ACFs because of sustainability and low-cost. Wood and lignin were often considered as suitable raw materials for ACFs preparation in previous studies [6-10]. Various processes have been developed to convert such bio-based raw materials into ACFs with large amount of porous structure, which can be applied in several significant fields, such as energy industry and wastewater treatment as well as gas phase adsorption.

The oil palm tree is an important agricultural biomass resource. Around 21.2 million ha of oil palm plantations were established worldwide for commercial oil production [11]. However, their oil productivity generally diminished after around 25 years old growth, resulting in replant of oil palm trees. This means that the massive amount of old felled oil palm trunks was produced at oil palm plantations, and it is essentially to deal with them in time because of large volume. Various methods had been explored for utilization of oil palm trunk, such as saccharification and fermentation for bio-ethanol [12], 
acid hydrolysis for cellulose nanocrystals [13,14], pyrolysis for bio-oil [15], mechanical processing for composite materials including laminated wood and plywood as well as particleboard [16-18]. To produce high value-added materials, preparation of ACFs from oil palm trunk seems to be a promising process.

Oil palm trunk contains high amount of carbohydrate polymers including cellulose and hemicellulose as well as starch, which are easily converted into liquefaction for eco-friendly products. In our previous study, oil palm trunk had been successfully liquefied with polyethylene glycol 400 (PEG 400) [19]. Precipitation of reaction mixture was performed to obtain insoluble substrate, named ligno-humin. The substrate contained around $60 \%$ of carbon, indicating a good precursor for fabricating carbonaceous materials. Besides, ligno-humin showed high molecular mobility at elevated temperature and could be directly subjected to melt-spinning without any further modification.

Accordingly, to broaden the utilization of oil palm trunk, in this article we describe the effects directed at the fabrication and characterization of ACFs. The effective chemical treatment of primary fibers was conducted to promote the conversion from fusible fibers into infusible fibers, which can be subjected to thermal treatment with high temperature. The pore structure of resultant ACFs were characterized by nitrogen adsorption and the surface chemical properties were determined with X-ray photoelectron spectroscopy. The adsorption capacity of ACFs were evaluated via liquid phase adsorption of chromium.

\section{Materials and Methods}

\subsection{Materials and Reagents}

30-year-old oil palm trunk was harvested from a replantation in Surat Thani province, Thailand. It was pulverized into powder with 40-60 mesh and then oven-dried before use. All chemicals including PEG 400, glycerol, sulfuric acid $\left(\mathrm{H}_{2} \mathrm{SO}_{4}\right)$, potassium dichromate $\left(\mathrm{K}_{2} \mathrm{Cr}_{2} \mathrm{O}_{7}\right)$, sodium hydroxide $(\mathrm{NaOH})$ and hydrochloric acid $(\mathrm{HCl})$ were purchased from commercial reagent suppliers and used as received in this experiment.

\subsection{ACFs Preparation}

Oil palm trunk powder were added into the mixture of PEG 400 and glycerol (4 to 1, w/w) as liquefaction solvent with the weight ratio of 1 to 3 in an around bottom flask which was set up with magnetic stirrer, thermometer, and reflux condenser system. The $98 \%$ sulfuric acid used as catalysis was added in flask with $2 \mathrm{wt} \%$ of the liquefaction solvent. Then flask was immersed in a silicone oil bath that was preheated at $180{ }^{\circ} \mathrm{C}$ for $30 \mathrm{~min}$. Afterward, the flask was cooled to room temperature in cold water bath to end the reaction. The 80\% 1,4-dioxane aqueous solution was added to the reaction product and then the resultant mixture was filtrated through filter paper to separate filtrated and residue. The 1,4-dioxane in filtrate was removed by evaporation. The resulting solution was then dropped into distilled water with continuous stirring for $1 \mathrm{~h}$. The precipitate was collected via filtration method and then freeze dried to obtained powder which was transformed into primary fiber by melt spinning at the temperature of $180^{\circ} \mathrm{C}$.

Subsequently, the obtained primary fiber was immersed in $10 \%$ sulfuric acid solution for $2 \mathrm{~h}$ at room temperature. After the specified time, the primary fiber was taken out from the acid solution and washed three times with distilled water. After dried in an oven at $60^{\circ} \mathrm{C}$ for $2 \mathrm{~h}$, the incubated fiber was heated in air from room temperature up to $250{ }^{\circ} \mathrm{C}$ with the heating rate of $5{ }^{\circ} \mathrm{C} / \mathrm{min}$ and held for $1 \mathrm{~h}$ in an electric furnace to obtain thermostabilized fiber. The carbonization and activation of thermostabilized fiber were carried out in the modified electrical tube furnace equipped with the gas inlet system. The thermostabilized fiber was heated from the room temperature to $600{ }^{\circ} \mathrm{C}$ with a heating rate of $5{ }^{\circ} \mathrm{C} / \mathrm{min}$ and held for $1 \mathrm{~h}$, and then the temperature increased to 700 to $900{ }^{\circ} \mathrm{C}$ with an equal heating rate of $10^{\circ} \mathrm{C} / \mathrm{min}$ and was maintained at the determined temperature for $30 \mathrm{~min}$ to $90 \mathrm{~min}$. The samples are referred to as T700-t60, T800-t60, T900-t60, T900-t30, and T900-t90, respectively. 
During the carbonization and activation process the flowing rate of $\mathrm{N}_{2}$ gas was $0.1 \mathrm{~L} / \mathrm{min}$, and the $\mathrm{CO}_{2}$ as activated gas was applied in the period of activation process with the flow rate of $0.3 \mathrm{~L} / \mathrm{min}$. The ACF was obtained after the temperature being reduced to room temperature under $\mathrm{N}_{2}$ gas.

\subsection{Characterization}

Image analysis was applied for the assessment of the fusibility of all primary fibers. The assessment of the fusibility of primary fibers was conducted with a microscope connected to a digital camera (Panasonic). The morphology in the cross-section and surface of fibers were observed by using scanning electron microscopy (SEM, Gemini SEM 500, Kanagawa, Japan) at an accelerating voltage of $15 \mathrm{kV}$. The fibers were sputtered with platinum under vacuum conditions before observation. The functional groups of each sample were determined by Fourier transform infrared (FTIR) spectrometry using the GX FT-IR system (PerkinElmer, Norwalk, CT, USA) over the scan range from $400 \mathrm{~cm}^{-1}$ to $4000 \mathrm{~cm}^{-1}$. A $1 \mathrm{mg}$ sample of sample powder was mixed with $99 \mathrm{mg}$ of finely ground potassium bromide and compressed to a disk for measurement. Thermogravimetric analysis (TGA) was carried out with TGA 1HT/1577 (Metter, Toledo, Germany). A sample was heated from room temperature to $600{ }^{\circ} \mathrm{C}$ with a heating rate of $10{ }^{\circ} \mathrm{C} / \mathrm{min}$ under an argon flow rate of $50 \mathrm{~mL} / \mathrm{min}$. The nitrogen adsorption-desorption isotherms were measured by using the Autosorb IQ surface area analyses (Autosorb-iQ; Quantachrome Instruments, Boynton Beach, FL, USA) for investigating the specific surface area and pore properties of ACF. A sample was degassed in a vacuum at $30{ }^{\circ} \mathrm{C}$ for $3 \mathrm{~h}$ before measurement at $77 \mathrm{~K}$. The specific surface area $\left(\mathrm{S}_{\mathrm{BET}}\right)$ was calculated using the Brunauer-Emmett-Teller (BET) model [20]. The total pore volume $\left(\mathrm{V}_{\text {tot }}\right)$ was determined from a relative pressure $(\mathrm{P} / \mathrm{Po})$ of 0.99. The micropore surface area and micropore volume were determined by following the $t$-plot method. While the Barrett-Joyner-Halends (BJH) method was applied for determining the mesopore surface area and mesopore volume, respectively [21-23]. The pore size distribution was calculated using the density functional theory (DFT) method [24]. The X-ray diffractometer was used with $\mathrm{Cu} \mathrm{Ka}$ radiation at wavelength of $0.154 \mathrm{~nm}$ under $40 \mathrm{kV}$ and $30 \mathrm{~mA}$. The scanning rate was $2^{\circ} / \mathrm{min}$ from $5^{\circ}$ to $80^{\circ}$. The X-ray photoelectron spectroscopy (XPS, Thermo Fischer ESCALAB $250 \mathrm{xi}$ ) was applied to investigate the functional groups on the surface of ACF with a monochromated $\mathrm{Al} \mathrm{Ka}$ X-ray source $(\mathrm{h} v=1486.6 \mathrm{eV})$. Each measurement was conducted twice to make sure the repeatability.

\subsection{Chromium Removal Experiments}

The chromium $(\mathrm{Cr}(\mathrm{VI}))$ removal efficiency were conducted to examine the adsorption capacity of ACFs. The stock $\mathrm{Cr}(\mathrm{VI})$ solution with the concentration of $1000 \mathrm{mg} / \mathrm{L}$ was prepared before use, which was further diluted to the required concentration. A definite amount of ACFs were added into $\mathrm{Cr}(\mathrm{VI})$ solution $(40-160 \mathrm{mg} / \mathrm{L})$ in flask, respectively. The flasks were sealed with paraffin film and then shaken with a rotation speed of $150 \mathrm{rpm}$ at $25 \pm 1{ }^{\circ} \mathrm{C}$ for a given time (15-240 min). After adsorption, the solution was immediately centrifuged for solid-liquid separation. The residual concentrations of $\mathrm{Cr}(\mathrm{VI})$ in filtrate were determined using a UV-vis spectrophotometer at a wavelength of $540 \mathrm{~nm}$ [25]. The $\mathrm{Cr}(\mathrm{VI})$ removal efficiency was calculated according to Equation (1):

$$
\mathrm{Cr}(\mathrm{VI}) \text { removal efficiency }(\%)=\left(C_{0}-C_{t}\right) / C_{0} * 100 \%
$$

where $C_{0}$ and $C_{t}$ are the $\mathrm{Cr}(\mathrm{VI})$ concentrations $(\mathrm{mg} / \mathrm{L})$ initially and at time $\mathrm{t}$, respectively.

As a blank, the concentration of $\mathrm{Cr}(\mathrm{VI})$ solution with no ACFs adsorption on each occasion were also measured. All experiments were performed at least in triplicate and the data were calculated as mean values. 


\section{Results}

\subsection{Infusible Precursor of ACFs}

Oil palm trunk was liquefied and then converted into primary fibers with the diameter of $47 \pm 6.8 \mu \mathrm{m}$ and tensile strength of $32.3 \pm 9.6 \mathrm{MPa}$. The water contact angle was $78^{\circ}$, indicating the hydrophilic property. The In general, the primary fiber obtained by melt-spinning, such as lignin fibers and polyacrylonitrile fibers as well as pitch fibers as precursors for CFs or ACFs, have been thermostabilized to maintain a fiber form during subsequent heating treatment with high temperature [26-28]. Thus, the primary fibers were subjected to thermostabilization upon heating up to $250{ }^{\circ} \mathrm{C}$ at varying low heating rates under air atmosphere. Unexpectedly, the primary fibers were very sensitive to the heating rates during thermostabilization and contacted with one another fusing together as observed in Figure 1B, indicating the unsuccessful thermostabilization under the conditions used.

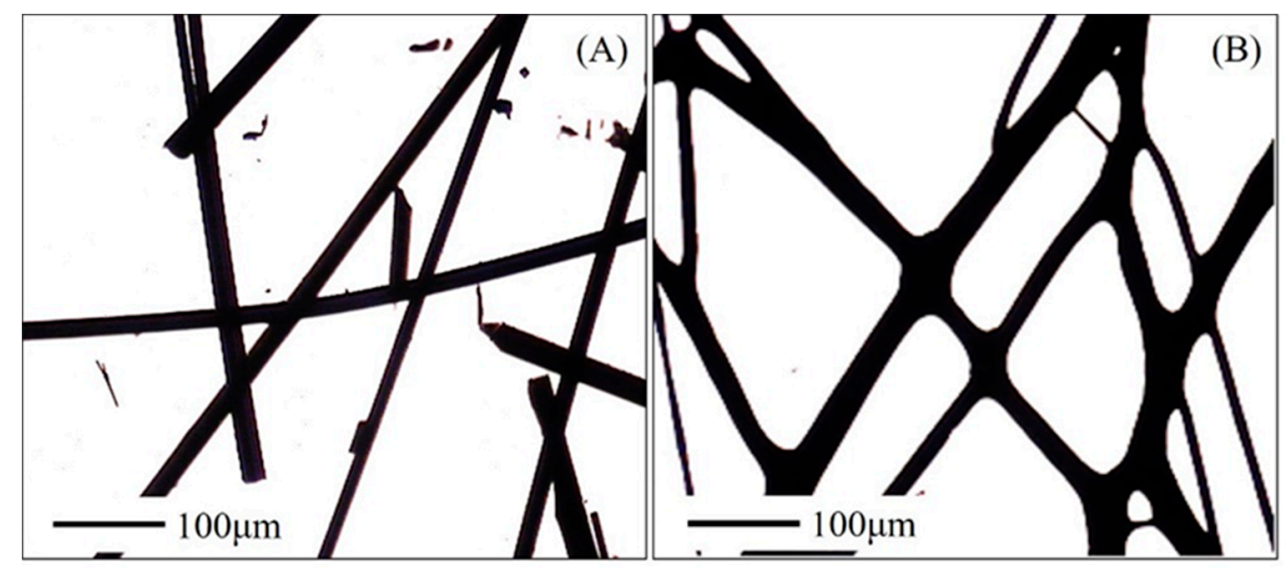

Figure 1. Microscopic images of the primary fiber (A) and thermostabilized fibers (B) heated in air from room temperature to $250{ }^{\circ} \mathrm{C}$ at the heating rate of $1^{\circ} \mathrm{C} / \mathrm{min}$.

To obtain infusible fibers, the primary fibers were treated by immersion in a dilute solution of sulfuric acid with differing concentrations of the range of $2 \%$ to $10 \%$. The resultant incubated fibers can resist the high temperature of $250{ }^{\circ} \mathrm{C}$ without melting by using a heating rate of $1{ }^{\circ} \mathrm{C} / \mathrm{min}$. Particularly, the primary fiber that was immersed in $8 \%$ sulfuric acid solution achieved a pre-oxidized heating rate of $3{ }^{\circ} \mathrm{C} / \mathrm{min}$, and the maximum heating rate of $5{ }^{\circ} \mathrm{C} / \mathrm{min}$ could only be used for the primary fiber treated with $10 \%$ sulfuric acid solution. These may be attributed to the partial cleavage of PEG moiety from primary fibers after incubation with diluted acid, which can be confirmed by decreasing in the intensity of C-H stretching vibration of methylene groups at $2930 \mathrm{~cm}^{-1}$ as showed in Figure 2A. Besides, the above result might be also caused by the diluted sulfuric acid solution failing to act as a catalyst for poly-condensation and cross-linking with the structure of the ligno-humin based primary fibers at low temperatures, resulting in the reformation of furanics in humin into phenolics and benzofurans [29-31]. For the thermal degradation characterization, the obtained incubated fiber showed more stable than primary fiber (Figure 2B), indicating that the chemical treatment with a dilute sulfuric acid solution at room temperature was helpful to improve the thermal stability of the primary fiber. After pre-oxidation, the oxidized fiber had great ability to resist temperatures and showed little weight loss, which can be subjected to carbonization and activation processes for the ACFs preparation. 

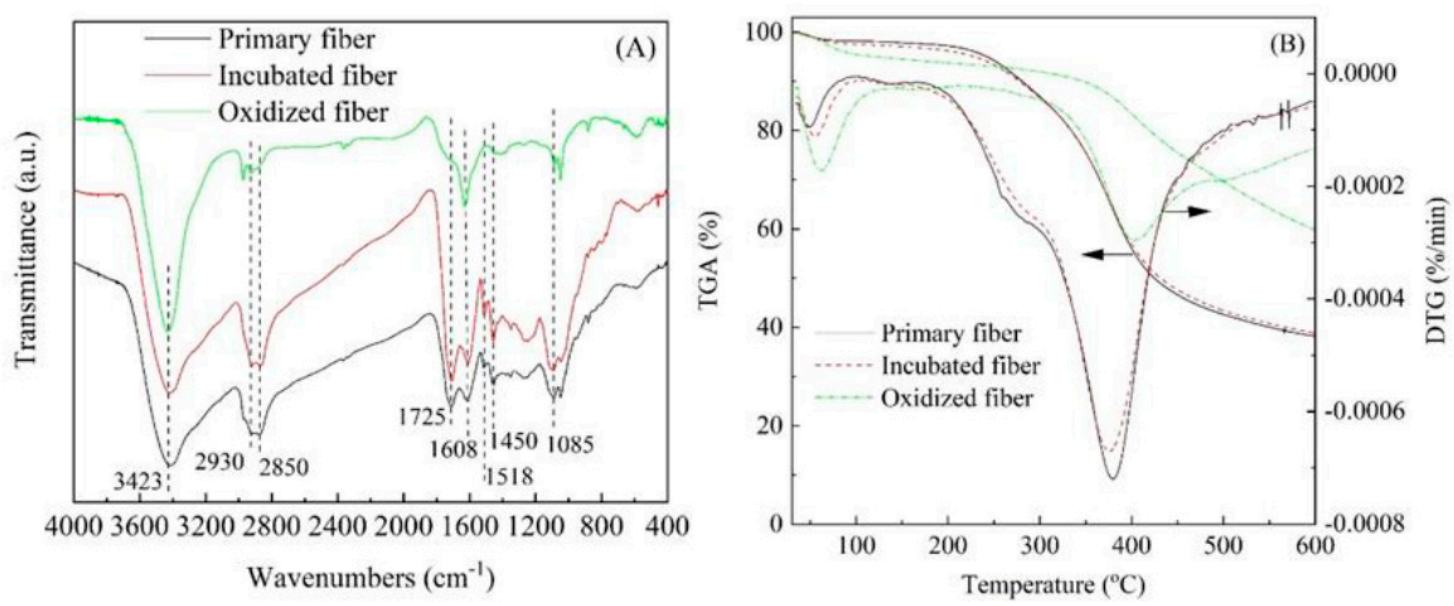

Figure 2. The FTIR spectrums (A) and TGA curves (B) of primary fiber, incubated fiber (10\% acid solutions) and the oxidized fiber with the heating rate of $5{ }^{\circ} \mathrm{C} / \mathrm{min}$.

\subsection{Porosity Characterization of ACFs}

The primary fiber obtained by melt spinning from liquefication of oil palm trunk was converted into ACFs through series of heating treatments. The activation temperature and time are the main key factors affecting the pore properties and characterization of ACFs. The effect of different activation temperatures in the rage of $700{ }^{\circ} \mathrm{C}$ to $900{ }^{\circ} \mathrm{C}$ and activation time from $30 \mathrm{~min}$ to $90 \mathrm{~min}$ on the porous structure of ACFs were investigated. The nitrogen adsorption-desorption isotherms of ACFs were given in Figure 3A. It is clearly that the ACFs prepared under different conditions of activation temperatures and times absorbed extremely high levels of nitrogen at low relative pressure $\left(P / P_{0}\right)$ and increased gradually as the relative pressure rose. According to the IUPAC classification, the adsorption behaviors belong to a Type I isotherm, indicating the microporous material [32]. However, at a high relative pressure above 0.4 the occurrences of some mesopore was also represented, especially at $900{ }^{\circ} \mathrm{C}$. Besides, the nitrogen adsorption ability of each of the ACFs raised when the activation temperature increased, the same as the amount of $\mathrm{S}_{\mathrm{BET}}$ and $\mathrm{V}_{\text {tot }}$ (as Table 1). The average pore dimension increased from 1.99 to $2.19 \mathrm{~nm}$ when the temperature increased from $700^{\circ} \mathrm{C}$ to $900^{\circ} \mathrm{C}$. The maximum peak of pore size distribution was indicated to be around $1.0 \mathrm{~nm}$ (Figure 3B). The activation temperature at $900{ }^{\circ} \mathrm{C}$ showed the highest $\mathrm{S}_{\mathrm{BET}}$ and $\mathrm{V}_{\text {tot }}$. Therefore, it was chosen for further study on the effect of activation time from $30 \mathrm{~min}$ to $90 \mathrm{~min}$ by fixing the $\mathrm{CO}_{2}$.
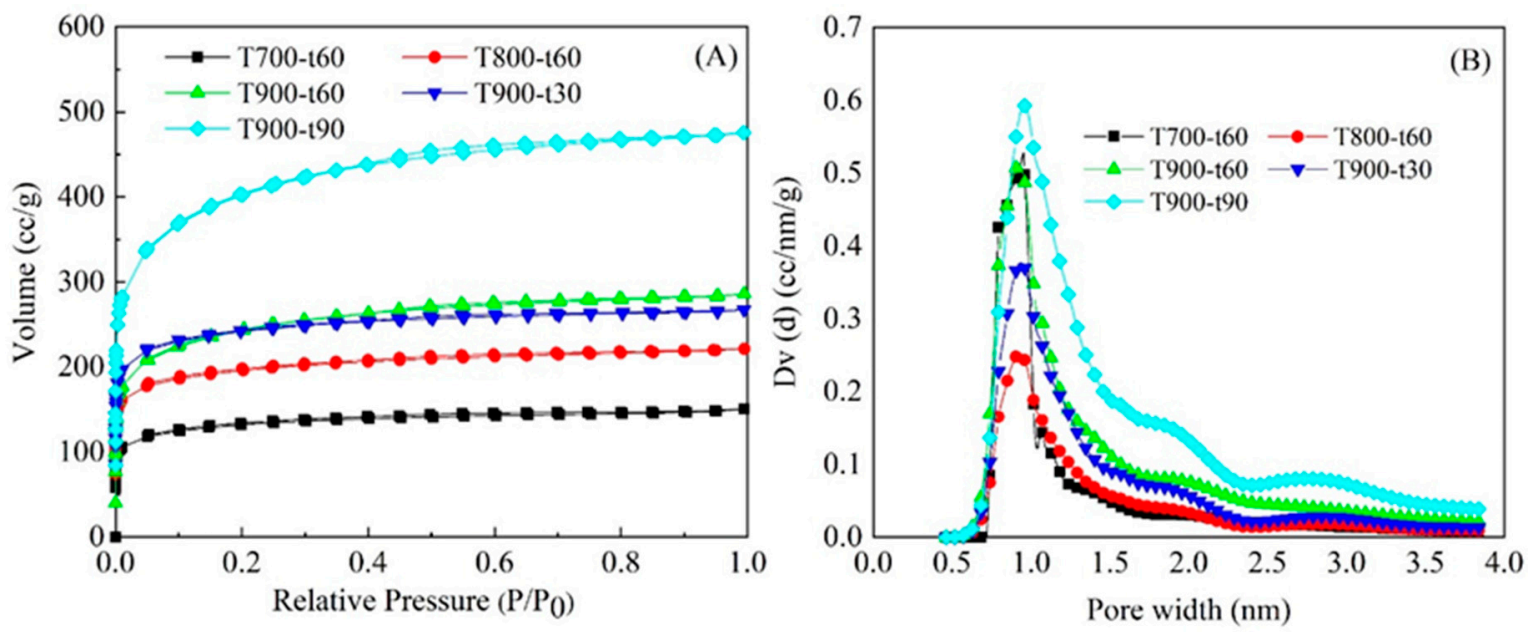

Figure 3. $\mathrm{N}_{2}$ adsorption-desorption isotherms (A) and pore width (B) of ACFs activated with different activation temperatures and times by fixing the $\mathrm{CO}_{2}$ gas flow rate at $300 \mathrm{~mL} / \mathrm{min}$. 
Table 1. The pore properties of ACFs.

\begin{tabular}{|c|c|c|c|c|c|c|c|c|}
\hline \multirow[t]{2}{*}{ Samples } & \multicolumn{3}{|c|}{$\begin{array}{l}\text { Specific Surface Area } \\
\qquad\left(\mathrm{m}^{2} / \mathrm{g}\right)\end{array}$} & \multicolumn{3}{|c|}{$\begin{array}{l}\text { Pore Volume } \\
\quad(\mathrm{cc} / \mathrm{g})\end{array}$} & \multirow[t]{2}{*}{$\% V_{\text {meso }}$} & \multirow{2}{*}{$\begin{array}{c}\text { Average Pore } \\
\text { Dimension } \\
\text { (nm) }\end{array}$} \\
\hline & $\mathrm{S}_{\text {BET }}$ & $\mathrm{S}_{\text {micro }}$ & $\mathrm{S}_{\text {meso }}$ & $\mathrm{V}_{\text {tot }}$ & $\mathrm{V}_{\text {micro }}$ & $\mathrm{V}_{\text {meso }}$ & & \\
\hline Precursor fibers & 4.3 & 1.9 & 2.9 & 0.001 & 0.000 & 0.001 & 100 & 4.00 \\
\hline T700-t60 & 542 & 438 & 171 & 0.234 & 0.200 & 0.096 & 41.0 & 1.99 \\
\hline T800-t60 & 857 & 665 & 231 & 0.343 & 0.296 & 0.128 & 37.3 & 1.90 \\
\hline T900-t60 & 1018 & 715 & 435 & 0.442 & 0.366 & 0.234 & 52.9 & 2.19 \\
\hline $\mathrm{T} 900-\mathrm{t} 30$ & 1109 & 830 & 280 & 0.413 & 0.364 & 0.148 & 35.8 & 1.87 \\
\hline T900-t90 & 1865 & 1132 & 835 & 0.735 & 0.588 & 0.436 & 59.3 & 2.27 \\
\hline
\end{tabular}

The activation time had obviously affected on the development of the $S_{B E T}$ and pore properties of ACFs. At $90 \mathrm{~min}$ it was $1865 \mathrm{~m}^{2} / \mathrm{g}$ which was contented with the highest $\mathrm{S}_{\mathrm{BET}}$ of micropore of $1132 \mathrm{~m}^{2} / \mathrm{g}$, corresponding to the nitrogen adsorption-desorption isotherm (Figure 3A). It also pointed out to micropore material mixed with some amount of mesopore. Remarkably, a prolonged holding time caused to an increase of mesopore. While all pore volumes increased as a function of time increased, the percentage of micropore dropped at $90 \mathrm{~min}$. The mesopore ratio was increased gradually from 35.8 to $59.3 \%$ after the time was changed from $30 \mathrm{~min}$ to $90 \mathrm{~min}$ in the same way as the average pore dimension which was shown largest at $90 \mathrm{~min}$ of $2.27 \mathrm{~nm}$. However, the pore size distribution of all activating time indicated that the shape peak between 0.75 to $1.4 \mathrm{~nm}$, which is the pore size of micropore (Figure 3B). Therefore, the use of a high activation temperature and long period of activation time significantly influenced the increased reaction between activating gas and carbon atom on the surface of precursor fiber which promoted to the creation of wide pores and had a trend to break due to the merging of some micropores into mesopores [33].

\subsection{Morphology}

Figure 4 illustrates the surface morphology of ACFs as a function of the activation temperatures and times. The results obtained from SEM analysis can be seen to confirm that the $\mathrm{CO}_{2}$ activating gas has a good ability for removing the carbon atoms from the surface of precursor fiber. It can clearly be seen that more various sizes of pore appeared on the fiber surface, compared to the original precursor fibers which have smooth surfaces. In consideration of the effect of activation temperature at a constant of the activation time for $60 \mathrm{~min}$ and $\mathrm{CO}_{2}$ flow rate at $300 \mathrm{~mL} / \mathrm{min}$, the $\mathrm{ACFs}$ activated at $700{ }^{\circ} \mathrm{C}$ showed a lot of tiny pinholes and some have wide pore on their surface. The pinhole pores were subsequently enlarged with the increase of the activation temperature, meanwhile, the new pores were also developed. Especially at $900{ }^{\circ} \mathrm{C}$, the resulting ACFs indicated the rising ratio of enlarged pores, corresponding with the pore properties that are shown in Table 1. The dominant pores in the resulting ACFs were micropore, however, the portion of mesopores increased when a high activation temperature and prolonged activation time were applied. Obviously, all the surfaces of the resulting ACFs activated at $900{ }^{\circ} \mathrm{C}$ and the various times from $30 \mathrm{~min}$ to $90 \mathrm{~min}$ by fixing the $\mathrm{CO}_{2}$ flow rate at $300 \mathrm{~mL} / \mathrm{min}$ appeared to have enlarged pores.

\subsection{Surface Chemistry}

Generally, the XPS is widely used to determine the changes in chemical bonding states and concentrations of surface functional groups that have high influences on the adsorption capacity of porous carbon material as well as the porosity properties [34]. The broad scan of XPS spectra and atomic concentrations on the surface of ACFs activated with different times at $900{ }^{\circ} \mathrm{C}$ and precursor fibers as a reference were presented in Figure 5A. All samples showed the similar XPS spectra patterns and indicated the main peaks in the position of C1s and O1s around 290 to $282 \mathrm{eV}$ and from 548 to $528 \mathrm{eV}$, respectively, suggesting that carbon atom and oxygen atom were the major component elements for ACFs. Compared with precursor fibers, ACFs showed relative low oxygen atom content. This may 
be caused by the de-oxygenation and aromatization of the structure of fibers under heating condition especially at high temperature, and surface oxides were removed by using $\mathrm{CO}_{2}$ as an oxidizing gas during activation process [35]. With the increase of activation time, the carbon atom content increased while the oxygen atom content decreased, revealing that more oxygen atom suffered content loss as prolonging the activating time. This was also a process of carbon atom enrichment.
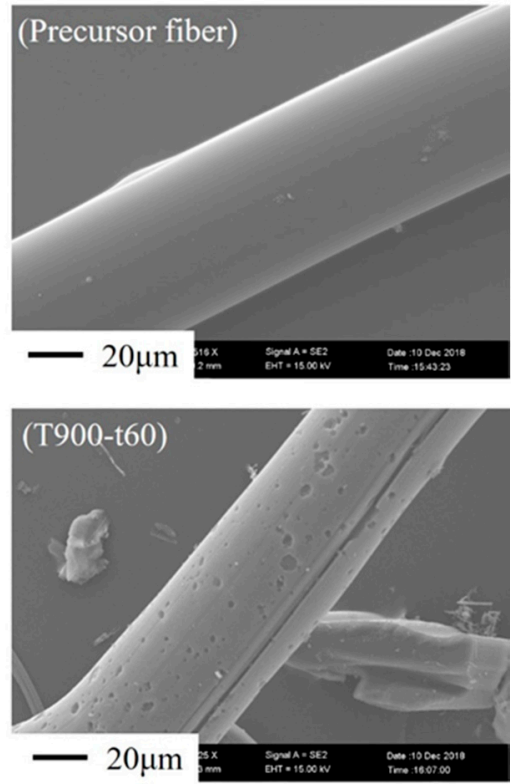
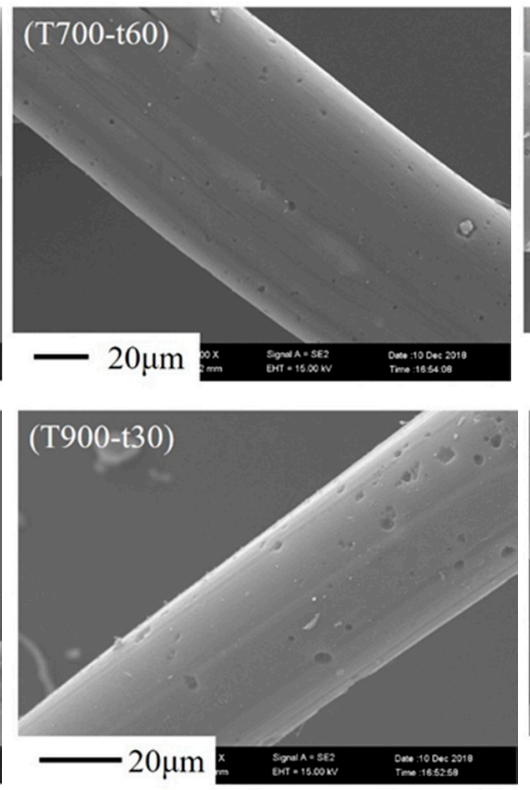
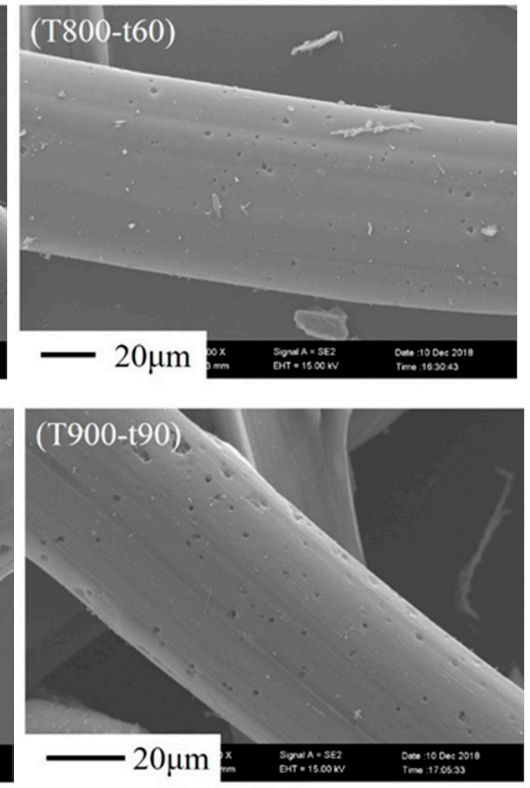

Figure 4. SEM micrographs of ACFs as a function of activation temperature and time.
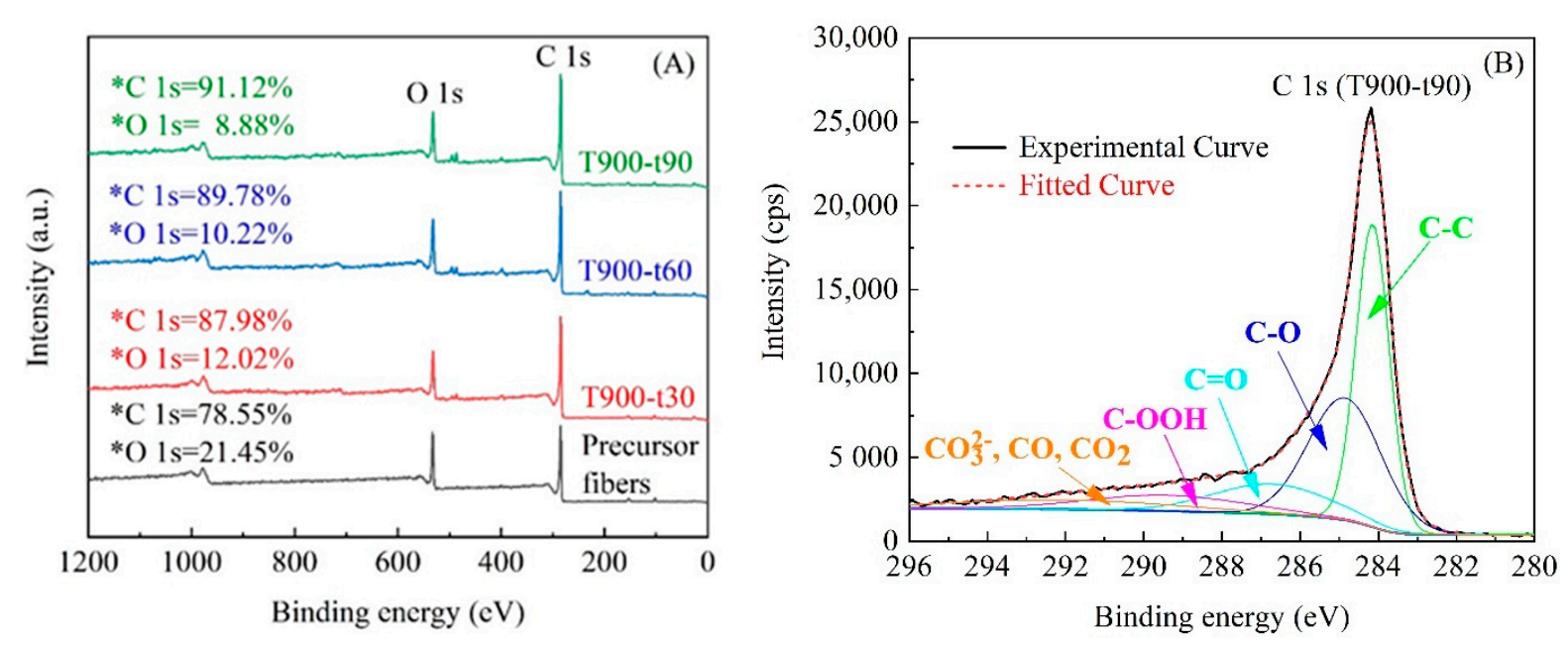

Figure 5. XPS spectrum of ACFs (A) and curve fitted high resolution XPS scans of T900-t90 for C1s (B).

The curve fitted high resolution XPS scans of T900-t90 for C1s spectrum were presented in Figure $5 \mathrm{~B}$ as an example. The $\mathrm{C} 1 \mathrm{~s}$ spectra was fitted into five individual component peaks [36]. Table 2 summarized the results of the fits of $C 1$ s region for all ACFs. The values in $\%$ intensity for graphitic carbon and oxygen-containing groups showed obvious differences among ACFs. A decreasing trend could be observed in graphitic carbon, whereas an opposite trend for carbon bonded to oxygen containing functions as the activation time increasing, indicating the higher extent of activation by $\mathrm{CO}_{2}$. Besides, the carbonyl groups and carboxylic groups as well as hydroxyl groups showed obvious increase, while the rest groups $\left(\mathrm{CO}_{3}{ }^{2-}, \mathrm{CO}, \mathrm{CO}_{2}\right)$ were showed the opposite changed tendency. 
Thus, it is believed that more graphitic carbons reacted with $\mathrm{CO}_{2}$ molecules to generate more functional groups containing $\mathrm{C}-\mathrm{O}$, which may be attributed to be an advantage on the chemical adsorption.

Table 2. Results of the fits of the $\mathrm{C} 1$ s region.

\begin{tabular}{cccccc}
\hline \multirow{2}{*}{ Samples } & \multicolumn{5}{c}{ Peak from C 1s Spectrum Binding Energy (\%) } \\
\cline { 2 - 6 } & $\mathbf{C}-\mathbf{C}$ & $\mathbf{C}-\mathbf{O H}$ & $\mathbf{C}=\mathbf{O}$ & $\mathbf{C O O H}$ & $\mathbf{C O}_{\mathbf{3}}{ }^{2-}, \mathbf{C O}, \mathbf{C O}_{\mathbf{2}}$ \\
\hline T900-t30 & 65.9 & 13.6 & 3.7 & 2.9 & 13.9 \\
T900-t60 & 58.1 & 20.2 & 4.7 & 4.3 & 12.7 \\
T900-t90 & 43.5 & 28.8 & 9.2 & 7.9 & 10.6 \\
\hline
\end{tabular}

\section{5. $\mathrm{Cr}($ VI) Removal Capacities}

$\mathrm{Cr}(\mathrm{VI})$ is one kind of the most important constituents among toxic compounds in the effluents, which may enter into body and cause serious health problems. Adsorption treatment is a fast and effective technology for the eradication of $\mathrm{Cr}(\mathrm{VI})$. Thus, all the ACFs were subjected to adsorb the $\mathrm{Cr}(\mathrm{VI})$ from aqueous solutions and each maximum adsorption capacity of ACFs were determined as shown in Figure 6. As increasing the activation time, the adsorption capacity of ACFs gradually increased. Especially, the highest adsorption capacity of $39.67 \mathrm{mg} / \mathrm{g}$ for T900-t90 was obtained, which was near two times greater than that of T900-t30. These results can be attributed to the porous structure and oxygen-containing functional groups on the surface of ACFs. Besides, the $\mathrm{Cr}(\mathrm{VI})$ adsorption value achieved in this study was higher than that of cotton-based ACFs and also comparable to that of AC and its fibric composite [37-39]. Consequently, ACFs in this study could be considered as an alternative material for the $\mathrm{Cr}(\mathrm{VI})$ removal.

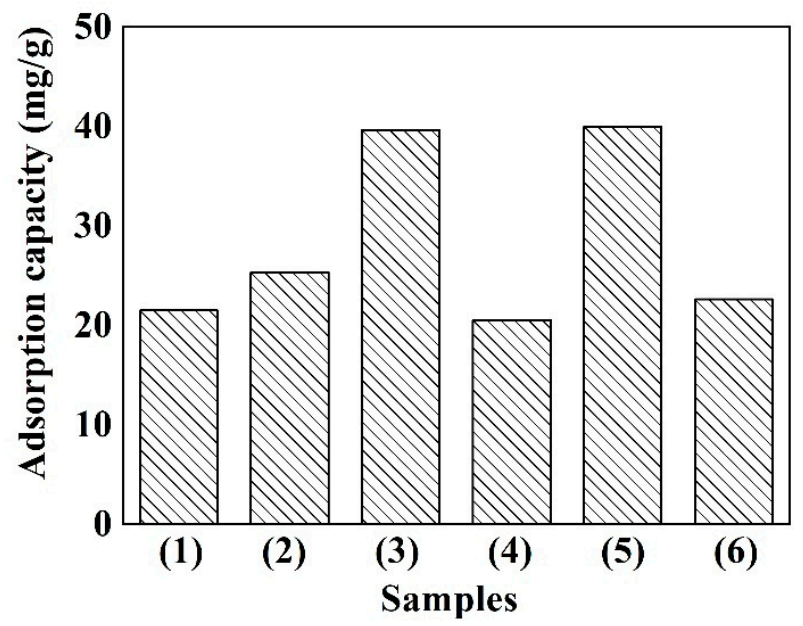

Figure 6. $\mathrm{Cr}(\mathrm{VI})$ adsorption capacity of various carbon materials. (1) T900-t30; (2) T900-t60; (3) T900-t90; (4) Cotton-based ACFs; (5) Bast-based AC; (6) AC/glass fiber fabric.

\section{Conclusions}

Oil palm trunk was liquefied with PEG-400 and then successfully converted into ACFs with porous structure by carbonization and $\mathrm{CO}_{2}$ activation. The chemical treatment with dilute sulfuric acid improved the thermal stability of primary fibers for following heating processes with high temperature. More pores, especially for the mesopores, were formed during activation process via increasing activating temperature and time. The ACFs prepared with T900-t90 in this study exhibited the highest $\mathrm{S}_{\mathrm{BET}}$ of around $1800 \mathrm{~m}^{2} / \mathrm{g}$ and $\mathrm{V}_{\text {tot }}$ of around $0.7 \mathrm{~mL} / \mathrm{g}$. Besides, the amount of oxygen-containing functional groups showed the same trend with $\mathrm{S}_{\mathrm{BET}}$ and pore volume with increasing activation time, which is attributed to high adsorption capacity of $\mathrm{Cr}(\mathrm{VI})$. Therefore, the resultant ACFs with highly 
porous structure and excellent $\mathrm{Cr}(\mathrm{VI})$ adsorption would be considered as an appropriate adsorbent for industrial sorption processes.

Author Contributions: J.L. did some part of experiments, data analysis and wrote the draft; R.C. did some part of experiments; G.Z. reviewed and revised the draft. All authors have read and agreed to the published version of the manuscript.

Funding: The research was financially supported by National Natural Science Foundation of China (No.31700492).

Conflicts of Interest: The authors declare no conflict of interest.

\section{References}

1. Jain, A.; Balasubramanian, R.; Srinivasan, M.P. Hydrothermal conversion of biomass waste to activated carbon with high porosity: A review. Chem. Eng. J. 2016, 283, 789-805. [CrossRef]

2. Zeng, F.L.; Pan, D. The structural transitions of rayon under the promotion of a phosphate in the preparation of ACF. Cellulose 2008, 15, 91-99. [CrossRef]

3. Ryu, S.K.; Kim, S.Y.; Gallego, N.; Edie, D.D. Physical properties of silver-containing pitch-based activated carbon fibers. Carbon 1999, 37, 1619-1625. [CrossRef]

4. Mangun, C.L.; Benak, K.R.; Economy, J.; Foster, K.L. Surface chemistry, pore sizes and adsorption properties of activated carbon fibers and precursors treated with ammonia. Carbon 2001, 39, 1809-1820. [CrossRef]

5. Sun, J.F.; He, C.J.; Zhu, S.J.; Wang, Q.R. Effects of oxidation time on the structure and properties of polyacrylonitrile-based activated carbon hollow fiber. J. Appl. Polym. Sci. 2007, 106, 470-474. [CrossRef]

6. Liu, W.J.; Zhang, Q.H.; Zhao, G.J. Influence of activation time on the microstructure and antibacterial activity of nanosilver-containing activated carbon fibers prepared from liquefied wood. Fibers Polym. 2015, 16, 522-528. [CrossRef]

7. Song, M.; Zhang, W.; Chen, Y.S.; Luo, J.M.; Crittenden, J.C. The preparation and performance of lignin-based activated carbon fiber adsorbents for treating gaseous streams. Front. Chem. Sci. Eng. 2017, 11, 328-337. [CrossRef]

8. Hu, S.X.; Zhang, S.L.; Pan, N.; Hsieh, Y.L. High energy density supercapacitors from lignin derived submicron activated carbon fibers in aqueous electrolytes. J. Power Sources 2014, 270, 106-112. [CrossRef]

9. Espinoza-Acosta, J.L.; Torres-Chavez, P.I.; Olmedo-Martinez, J.L.; Vega-Rios, A.; Flores-Gallardo, S.; Zaragoza-Contreras, E.A. Lignin in storage and renewable energy application: A review. J. Energy Chem. 2018, 27, 1422-1438. [CrossRef]

10. Dong, X.Z.; Lu, C.X.; Zhou, P.C.; Zhang, S.C.; Wang, L.Y.; Li, D.H. Polyacrylonitrile/lignin sulfonated blend fiber for low-cost carbon fiber. RSC Adv. 2015, 5, 42259-42265. [CrossRef]

11. Komariah, R.N.; Miyamato, T.; Tanaka, S.; Prasetiyo, K.W.; Syamani, F.A.; Subyakto; Umezawa, T.; Kanayama, K.; Umemura, K. High-performance binderless particle board from the inner part of oil palm trunk by addition of ammonium dihydrogen phosphate. Ind. Crop Prod. 2019, 141, 111761. [CrossRef]

12. Prawitwong, P.; Kosugi, A.; Arai, T.; Deng, L.; Lee, K.C.; Ibrahim, D.; Murata, Y.; Sulaiman, O.; Hashim, R.; Sudesh, K.; et al. Efficient ethanol production from separated parenchyma and vascular bundle of oil palm trunk. Bioresour. Technol. 2012, 125, 37-42. [CrossRef] [PubMed]

13. Lamaming, J.; Hashim, R.; Sulaiman, O.; Leh, C.P.; Sugimoto, T.; Nordin, N.A. Cellulose nanocrystals isolated from oil palm trunk. Carbohyd. Polym. 2015, 127, 202-208. [CrossRef]

14. Lamaming, J.; Hashim, R.; Leh, C.P.; Sulaiman, O.; Sugimoto, T.; Nasir, M. Isolation and characterization of cellulose nanocrystals from parenchyma and vascular bundle of oil palm trunk (Elaeis guineensis). Carbohyd. Polym. 2015, 134, 534-540. [CrossRef] [PubMed]

15. Oramahi, H.A.; Wahdina; Diba, F.; Nurhaida; Yoshimura, T. Optimization of production of Lignocellulosic biomass bio-oil from oil palm trunk. Procedia Environ. Sci. 2015, 28, 769-777. [CrossRef]

16. Lee, S.H.; Ashaari, Z.; Ang, A.F.; Halip, J.A.; Lum, W.C. Effects of two-step post heat-treatment in palm oil on the properties of oil palm trunk particleboard. Ind. Crop Prod. 2018, 116, 249-258. [CrossRef]

17. Aizat, A.G.; Zaidon, A.; Nabil, F.L.; Bakar, E.S.; Rasmina, H. Effects of diffusion process and compression on polymer loading of laminated compreg oil palm (Elaeis guineensis) wood and its relation to properties. J. Biobased Mater. Bio. 2014, 8, 519-525. [CrossRef]

18. Khalil, H.P.S.A.; Nur Firdaus, M.Y.; Jawaid, M.; Anis, M.; Ridzuan, R.; Mohamed, A.R. Development and material properties of new hybrid plywood from oil palm biomass. Mater. Des. 2010, 31, 417-424. [CrossRef] 
19. Choowang, R.; Lin, J.; Zhao, G.J. Efficiency of blended polyhydric alcohols solution on liquefaction of oil palm trunk (Elaeis guineensis Jacq.). Bioresources 2019, 14, 2759-2772.

20. Okada, K.; Yamamoto, N.; Kameshima, Y.; Yasumori, A. Porous properties of activated carbons from waste newspaper prepared by chemical and physical activation. J. Colloid Interface Sci. 2003, 262, 179-193. [CrossRef]

21. Azargohar, R.; Dalai, A.K. Steam and KOH activation of biochar: Experimental and modeling studies. Micropor. Mesopor. Mater. 2008, 110, 413-421. [CrossRef]

22. Shimada, M.; Iida, T.; Kawarada, K.; Chiba, Y.; Mamoto, T.; Okayama, T. Porous structure of activated carbon prepared from waste newspaper. J. Mater. Cycles Waste Manag. 2000, 2, 100-108.

23. RodriguezReinoso, F.; LopezGonzalez, J.D.; Berenguer, C. Activated carbon from almost shells-II: Characterization of the pore structure. Carbon 1984, 22, 13-18. [CrossRef]

24. Lastoskie, C.; Gubbins, K.E.; Quirke, N. Pore size distribution analysis of microporous carbon: A density functional theory approach. J. Phys. Chem. 1993, 97, 4786-4796. [CrossRef]

25. Troppová, I.; Matějová, L.; Kuboňová, L.; Strašák, T.; Študentová, S.; Kustrowski, P.; Obalová, L. Molecular dimensions and porous structure of activated carbons for sorption of xylene and isoocatane. Chem. Eng. Technol. 2017, 40, 6-17. [CrossRef]

26. Kadla, J.F.; Kubo, S.; Venditti, R.A.; Gilbert, R.D.; Compere, A.L.; Griffith, W. Lignin-based carbon fiber for composite fiber applications. Carbon 2002, 40, 2913-2920. [CrossRef]

27. Morita, K.; Miyachi, H.; Hiramatsu, T. Stabilization of acrylic fibers by sulfur atoms mechanism of stabilization. Carbon 1981, 19, 11-18. [CrossRef]

28. Lin, S.S. Oxidative stabilization in production of pitch based carbon-fiber. Sampe J. 1991, 27, 9-14.

29. Kim, K.W.; Lee, H.M.; Kim, B.S.; Hwang, S.H.; Kim, B.J. Preparation and thermal properties of polyethylene-based carbonized fibers. Carbon Lett. 2015, 16, 62-66. [CrossRef]

30. Yoo, M.J.; Ko, H.J.; Lim, Y.S.; Kim, M.S. Modification of isotropic coal-tar pitch by acid treatments for carbon fiber melt-spinning. Carbon Lett. 2014, 15, 247-254. [CrossRef]

31. Rasrendra, C.B.; Windt, M.; Wang, Y.; Adisasmito, S.; Makertihartha, I.G.B.N.; Van Eck, E.R.H.; Meier, D.; Heeres, H.J. Experimental studies on the pyrolysis of humins from the acid-catalysed dehydration of C6-sugars. J. Anal. Appl. Pyrolysis 2013, 104, 299-307. [CrossRef]

32. Qin, W.; Kadla, J.F. Carbon fibers based on pyrolytic lignin. J. Appl. Polym. Sci. 2011, 126, E203-E212. [CrossRef]

33. Duan, X.H.; Srinivasakannan, C.; Yang, K.B.; Yang, K.B.; Peng, J.H.; Zhang, L.B. Effects of heating method and activating agent on the porous structure of activated carbons from coconut shells. Waste Biomass Valor. 2012, 3, 131-139. [CrossRef]

34. Ma, X.; Chen, Y. Preparation and characterization of Mn/N co-doped TiO2 loaded on wood-based activated carbon fiber and its visible light photodegradation. Polymers 2015, 7, 1660-1673. [CrossRef]

35. Hoang, T.M.C.; Van Eck, E.R.H.; Bula, W.P.; Gardeniers, J.G.E.; Lefferts, L.; Seshan, K. Humin based by-product from biomass processing as a potential carbonaceous source for synthesis gas production. Green Chem. 2015, 17, 959-972. [CrossRef]

36. Chiang, Y.C.; Lee, C.C.; Lee, H.C. Characterization of microstructure and surface properties of heat-treated PAN-and rayon-based activated carbon fibers. J. Porous Mater. 2007, 14, 227-237. [CrossRef]

37. Lee, I.; Park, J.A.; Kang, J.K.; Kim, J.H.; Son, J.W.; Yi, I.G.; Kim, S.B. Batch and Flow-Through Column Studies for $\mathrm{Cr}(\mathrm{VI})$ Sorption to Activated Carbon Fiber. Environ. Eng. Res. 2014, 19, 157-163. [CrossRef]

38. Gupta, V.K.; Pathania, D.; Sharma, S.; Singh, P. Preparation of bio-based porous carbon by microwave assisted phosphoric acid activation and its use for adsorption of Cr(VI). J. Collid Interface Sci. 2013, 401, 125-132. [CrossRef]

39. Huang, M.L.; Mishra, S.B.; Liu, S.Q. Waste Glass Fiber Fabric as a Support for Facile Synthesis of Microporous Carbon to Adsorb Cr(VI) from Wastewater. ACS Sustain. Chem. Eng. 2017, 5, 8127-8136. [CrossRef]

Publisher's Note: MDPI stays neutral with regard to jurisdictional claims in published maps and institutional affiliations. 